\title{
Efficient RT-PCR tool for tomato spotted wilt virus detection in its vectors Thrips tabaci and Frankliniella occidentalis
}

\author{
Z. W. ŠUBR ${ }^{1}$, K. D. KIRÁLY², J. FAIL ${ }^{2}$, A. ALMÁSI ${ }^{3}$, K. SALÁNKI ${ }^{3}$, P. FEDOR ${ }^{4}$
}

\begin{abstract}
${ }^{1}$ Institute of Virology, Biomedical Research Center of the Slovak Academy of Science, Dúbravská cesta 9, 84505 Bratislava, Slovakia; ${ }^{2}$ Szent Istvan University, Faculty of Horticultural Science, Department of Entomology, Ménesi str. 44, H-1118 Budapest, Hungary; ${ }^{3}$ Hungarian Academy of Science, Centre for Agricultural Research, Plant Protection Institute, Department of Plant Pathology, H-1022 Budapest, Hungary; ${ }^{4}$ Dpt. Environmental Ecology, Faculty of Natural Sciences, Comenius University Bratislava, 84215 Bratislava, Slovakia
\end{abstract}

Received June 21, 2019; accepted July 12, 2019

Keywords: tospovirus; thrips

Tospoviruses (the family Bunyaviridae, the genus Tospovirus) are ssRNA viruses with tripartite genome and ambisense expression strategy. Three genome segments (L, M, S) are packed together in spherical enveloped virions about $100 \mathrm{~nm}$ in diameter (1). The type member of the genus, tomato spotted wilt virus (TSWV) causes significant losses of vegetable and ornamental crops worldwide. It possesses a wide host range, mainly from the families Asteraceae, Fabaceae and Solanaceae. TSWV is naturally transmitted by several species of thrips in a circulative and propagative manner (2). The virus is transmissible exclusively by the adult individuals, which had acquired it by feeding during their larval stage. For this purpose, tospoviruses are able to manipulate the diet preference of their vectors to maximize the transmission efficiency (3). Several methods have been applied to detect TSWV either in plants or inside the thrips vectors (4). Here we show a specific and sensitive RT-PCR able to confirm the TSWV presence in individual thrips bodies.

The TSWV (isolate HUP2-2012-RB) originated from Capsicum annuum cv. Brendon from Szegvár, Hungary (5) and was mechanically passaged in young plants of Capsicum annuum cv. Brody, Nicotiana tabacum cv. Xanthi-nc and Nicotiana benthamiana.

E-mail: virusubr@savba.sk; phone: +421-2-59302 447. Abbreviations: $\mathrm{TSWV}=$ tomato spotted wilt virus, $\mathrm{COI}=\mathrm{cy}$ tochrome oxidase subunit I
Thrips rearing was performed in a growth chamber at $23^{\circ} \mathrm{C}$ with 16:8 (L:D) photoperiod. Larvae of the tobaccoassociated (6) onion thrips (Thrips tabaci) in their early larval stages were reared on leaf disks of infected Nicotiana species, and larvae of the western flower thrips (Frankliniella occidentalis) on leaf disks of infected pepper. Later, all the larvae were transferred individually to leaf disks of uninfected $N$. tabacum cv. Hevesi $9 \mathrm{~F}_{1}$ (T. tabaci), or uninfected Phaseolus vulgaris cv. Lingua Di Fuoco (F. occidentalis) to complete their development. Evolved adults were transferred to uninfected petunia (Petunia x hybrida cv. Surfinia Double Blue Star) leaf disks for up to five days (or until they died), then the thrips were killed and stored in $96 \%$ ethanol.

RNA from infected pepper leaves was isolated by the $\mathrm{Nu}-$ cleospin RNA Plant kit (Macherey Nagel), thrips RNA was obtained by TRIZOL method from potentially viruliferous individuals or pools of F. occidentalis and T. tabaci. The thrips captured individually under ethanol in microcentrifuge tubes were air-dried and homogenized by a micropestle in TRIreagent (Sigma) followed by standard TRIZOL RNA isolation (4). Total cDNA was prepared by AMV reverse transcriptase using random hexamer primers (Promega). The primer pair TS2for (5'-TTTAGCATTAGGATTGCTGG-3')/ TS2rev (5'-ATCATGTCTAAGGTTAAGCTC-3') spanning a $684 \mathrm{nt}$ long part of the TSWV nucleoprotein gene $\mathrm{N}$ were designed according the sequence of TSWV S RNA (Acc. No. KY495612) (Table 1).

PCR conditions optimized using GO Taq DNA polymerase (Promega) with cDNA from TSWV-infected plants were 


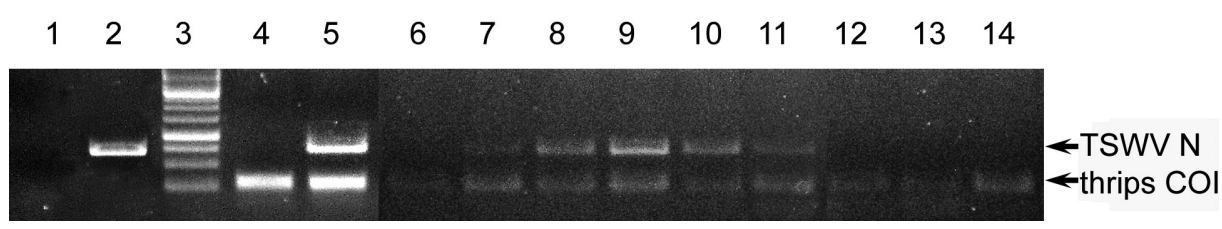

Fig. 1

RT-PCR detection of TSWV

Lane 1 - negative PCR control (water instead of template), lane 2 - positive control for TS2 primers (cloned fragment as template), lane 3 - 1 kb DNA ladder, lane 4 - positive control for FoCO primers (cloned fragment as template), lane 5 - positive control for duplex PCR (mix of template plasmids), lane 6 - T. tabaci (individual), lane 7 - T. tabaci (individual), lane 8 - T. tabaci (pool of two), lane 9 - F. occidentalis (pool of five), lane 10 - F. occidentalis (pool of two), lane 11 - F. occidentalis (individual), lane 12 - F. occidentalis (individual), lane 13 - F. occidentalis (individual), lane 14 - stock colony F. occidentalis (pool of two). Electrophoresis in $1.5 \%$ agarose gel.

as follows: 3 min dentauration at $95^{\circ} \mathrm{C}, 40$ cycles of $(15 \mathrm{~s}$ denaturation at $95^{\circ} \mathrm{C}, 20 \mathrm{~s}$ annealing at $56^{\circ} \mathrm{C}, 45 \mathrm{~s}$ elongation at $72^{\circ} \mathrm{C}$ ), $10 \mathrm{~min}$ final elongation at $72^{\circ} \mathrm{C}$. Obtained specific band was extracted from the agarose gel by Wizard SV Gel and PCR Cleanup System (Promega), verified by sequencing and cloned into pGEM-Teasy (Promega) to gain a stable positive PCR control. The estimated PCR detection sensitivity was at least $10 \mathrm{pg} / \mathrm{ml}$ of plasmid DNA.

While none of tested commercial kits for RNA isolation lead to positive RT-PCR results using thrips RNA (data not shown), RT-PCR with TRIZOL-isolated RNA from individual thrips resulted in faint, but well detectable bands using TS2for/TS2rev primers. For the internal control of thrips RNA quality a primer set FoCOfor (5'-GCAGGAA CAGGATGAACAG-3')/FoCOrev (5'-TTTCGGTCAGT TAAAAGTATTG-3') was designed to amplify a $275 \mathrm{nt}$ long fragment of insect mitochondrial cytochrome oxidase subunit I gene (based on several COI sequences of T. tabaci and F. occidentalis) and the PCR product was cloned to obtain a control template as described above. As the control PCR run under the same conditions as TSWV-specific detection, both primer pairs could be applied simultaneously in a duplex PCR (Fig. 1). Either individual or pooled thrips samples were analyzed and most of them were shown TSWV-positive. Sequence analysis confirmed the specifity of amplimers obtained from the insects. Analysis of F. occidentalis from the stock colony comprising females, which only fed on TSWV-infected pepper leaf disks as adults (thus unable to transmit the virus), resulted in positive reaction with the internal control primers, but no TSWV-specific band was observed (Fig. 1, lane 14). Obviously, the reaction sensitivity did not enable to detect the virus without its amplification during the propagative stage in the thrips.

Because of high economic importance of TSWV, several protocols for its molecular detection have been described including immunocapture RT-PCR (7), multiplex RT-PCR to detect up to five different tospoviruses in plants $(8)$ and conventional or TaqMan-based real-time RT-PCR analysis of individual thrips $(4,9)$. Our RT-PCR protocol was also able to detect TSWV not only in infected plants, but also in individual viruliferous thrips following simple and relatively fast RNA isolation. The total time needed for analysis of up to ten samples (from sample preparation to gel documentation) did not exceed six hours (up to $2 \mathrm{~h}$ RNA isolation, $1.5 \mathrm{~h}$ reverse transcription, $2 \mathrm{~h}$ PCR, 30 min electrophoresis). The main benefit of our approach was successful involvement of internal control for the most critical point, namely for quality of RNA prepared from the tiny thrips bodies.

Acknowledgments. Andrea Tilly-Mándy and Peter Farkas are acknowledged for technical assistance. This study was supported by the grant 2/0032/18 from the Scientific Grant Agency of Ministry of Education and Slovak Academy of Sciences (VEGA) and by the Higher Education Institutional Excellence Program of the Hungarian Ministry of Human Capacities within the framework of plant breeding and plant protection researches (20430-3/2018/ FEKUTSTRAT) at Szent István University. J. Fail was supported by the János Bolyai Research Scholarship of the Hungarian Academy of Sciences.

\section{References}

1. Pappu HR, Jones RAC, Jain RK, Virus Res. 141, 219-236, 2009. https://doi.org/10.1016/j.virusres.2009.01.009

2. Rotenberg D, Jacobson AL, Schneweis DJ, Whitfield AE, Curr. Opin. Virol. 15, 80-89, 2015. https://doi.org/10.1016/j. coviro.2015.08.003

3. Shalileh S, Ogada PA, Moualeu DP, Poehling HM, Environ. Entomol. 45, 1235-1242, 2016. https://doi.org/10.1093/ ee/nvw102

4. Mason G, Roggero P, Tavella L, J. Virol. Methods 109, 69-73, 2003. https://doi.org/10.1016/S0166-0934(03)00048-X

5. Almási A, Csilléry G, Csömör Z, Nemes K, Palkovics L, Salánki K, Tóbiás I, Virus Genes 50, 71-78, 2015. https://doi. org/10.1007/s11262-014-1131-3 
6. Brunner PC, Chatzivassiliou EK, Katis NI, Frey JE, Heredity 93 , 364-370, 2004. https://doi.org/10.1038/sj.hdy.6800512

7. Jain RK, Pappu SS, Pappu HR, Culbreath AK, Todd JW, Plant Dis. 82, 900-904, 1998. https://doi.org/10.1094/ PDIS.1998.82.8.900
8. Uga H, Tsuda S, Phytopathology 95, 166-171, 2005. https://doi. org/10.1094/PHYTO-95-0166

9. Boonham N, Smith P, Walsh K, Tame J, Morris J, Spence N, Bennison J, Barker I, J. Virol. Methods 101, 37-48, 2002. https://doi.org/10.1016/S0166-0934(01)00418-9 